\title{
Ecology of Icerya purchasi Maskell, 1879 (Homoptera: Margarodidae) on clementine trees at Sidi Moussa (Central Mitidja, Algeria)
}

\author{
Boukhobza L. ${ }^{1}$, Belguendouz R. $^{2}$, Biche M. ${ }^{1 *}$ \\ ${ }^{1}$ National Higher School of Agronomy 16200 El Harrach Algiers, Algeria \\ ${ }^{2}$ Laboratory of Medicinaland Aromatic Plants, DepartmentofBiotechnologies, Faculty S.N.V Universityof \\ Blida 1 - Algeria \\ Corresponding author email: m.biche@ensa.dz \\ Received; 08.10.2020. Accepted; 20.11.2020
}

\begin{abstract}
In order to establish the better communication between applied entomology and fundamental ecology to consider an integrated control against the Australian cochineal Icerya purchasi Maskell, 1879 (Homoptera: Margarodidae) the most formidable pest for citrus fruits, a study on the Spatio-temporal dynamics of the parasite were followed for two years in a clementine orchard in Western Mitidja in Algeria. Ten-day samples of leaves and twigs were carried out from 2017 to 2018 . The level of I. purchasi infestation is very high throughout the study period when the minimum threshold exceeds 400 individuals, with three intense periods of infestations: spring, summer and fall during the two years. The population of young larval stages is the largest during the two years of study with 13,323 individuals (62.8\%) and 13,968 individuals (54.4\%) in 2017 and 2018 respectively against 7896 individuals (37.2 \%) in 2017 and 11,715 individuals (33.5 \%) in 2018 for adults. Tukey's pairwise comparison test on the companion plan shows that the 2018 one is the most important from an overall effective point of view (ANOVA, $p<0.01$, Tukey's test $p<0.01$ ). The Cross-Correlation Test shows the presence of a time lag $(p=0.0371, p<0.05)$ and the maximum overall abundance was reported around mid-July for both campaigns. Statistical tests show that females show the same fertility during the two campaigns (ANOVA, p >0.05). peak fertility in 2017 was reported in mid-June, while peak fertility was reported in mid-July for the 2018 campaign. The Cross-Correlation Test shows a very significant time lag from one month to another $(p=0.0064, p<0.01)$
\end{abstract}

Key words: Ecology, Icerya purchasi, Citrus, Sidi Moussa, Algiers

\section{Introduction}

Scale insects or coccidae are the most formidable enemies of citrus fruit, both in terms of the qualitative and quantitative depreciation they cause to the fruit as well as its tree. Depending on the intensity of the attacks, partial or total dieback of some branches or even the whole tree can be observed due to the intense spoliation of the tree's sap, causing it to weaken (Bailet, 2011). Among the Margarodidae, the most worrying species for citrus orchards is $I$. purchasi, commonly known as the Australian mealybug. It originates from Australia but has spread to all parts of the world (DeBach, 1964). It is considered a major pest of citrus (Carvalho et al., 1996). Damage by this scale insect is both direct (sap extraction, wounds on the bark, deformations and seeps) as well as indirect, through a high production of honeydew which allows the development of sooty mold. In the absence of treatments and natural enemies, this damage compromises production and can lead to citrus tree death (Kiyindou, 2008; Mbete et al., 2011). Causton et al., (2004) reported that $I$. purchasi presents a serious threat to plants, difficult to control even with pesticides.

Algeria was traditionally a citrus exporting country and is currently having trouble in meeting local consumption needs, which are constantly increasing due to the consumption of fresh fruit (Boudi, 2005). On the other hand, the marketing of citrus fruits is facing enormous difficulties. Particulularly, the sanitary quality, due to diseases and pests that make them unfit for consumption, preservation and export, depriving Algeria of foreign exchange earnings (Belguendouz, 2014).

This remains the first study to be conducted on the ecology of $I$. purchasi in Algeria. Although, much research has been carried out on the bioecology of scale insects, mainly citrus, especially on Diaspines (Biche, Sellami, 1999; Biche et al., 2012; Chafaa et al., 2013a, 2013b; Belguendouz et al., 2014; Aroua et al., 2019; Aroua et al., 2020), Pseudococcins (Aroua et al., 2019), Asterolecanins (Menzer et al. 2016) and Lecanins (Biche et al., 2012). We provide information on some bioecological parameters such as population dynamics and spatial and temporal distribution of the pest on the tree, which will be useful for better management of this pest.

\section{Materials and methods}

\section{Study site}

Our study was carried out in a farm in the region of Sidi Moussa, $\left(36^{\circ} 35^{\prime} 47.9^{\prime \prime} \mathrm{N} 3^{\circ} 05^{\prime} 38.6^{\prime \prime E}\right)$ located at the level of the Mitidja plain, Algiers (Figure 1). The farm covers an area of 2.5 hectares and contains 690 clementine trees of the Nules variety grafted on citrange carrizo (Citrus sinensis (L.) 'Washington' $\times$ Poncirus trifoliata (L.)). The choice of the site was selected because of the heavy infestation of the Australian scale, which remains a threat to neighbouring plots and the importance of citrus yards in the region. 


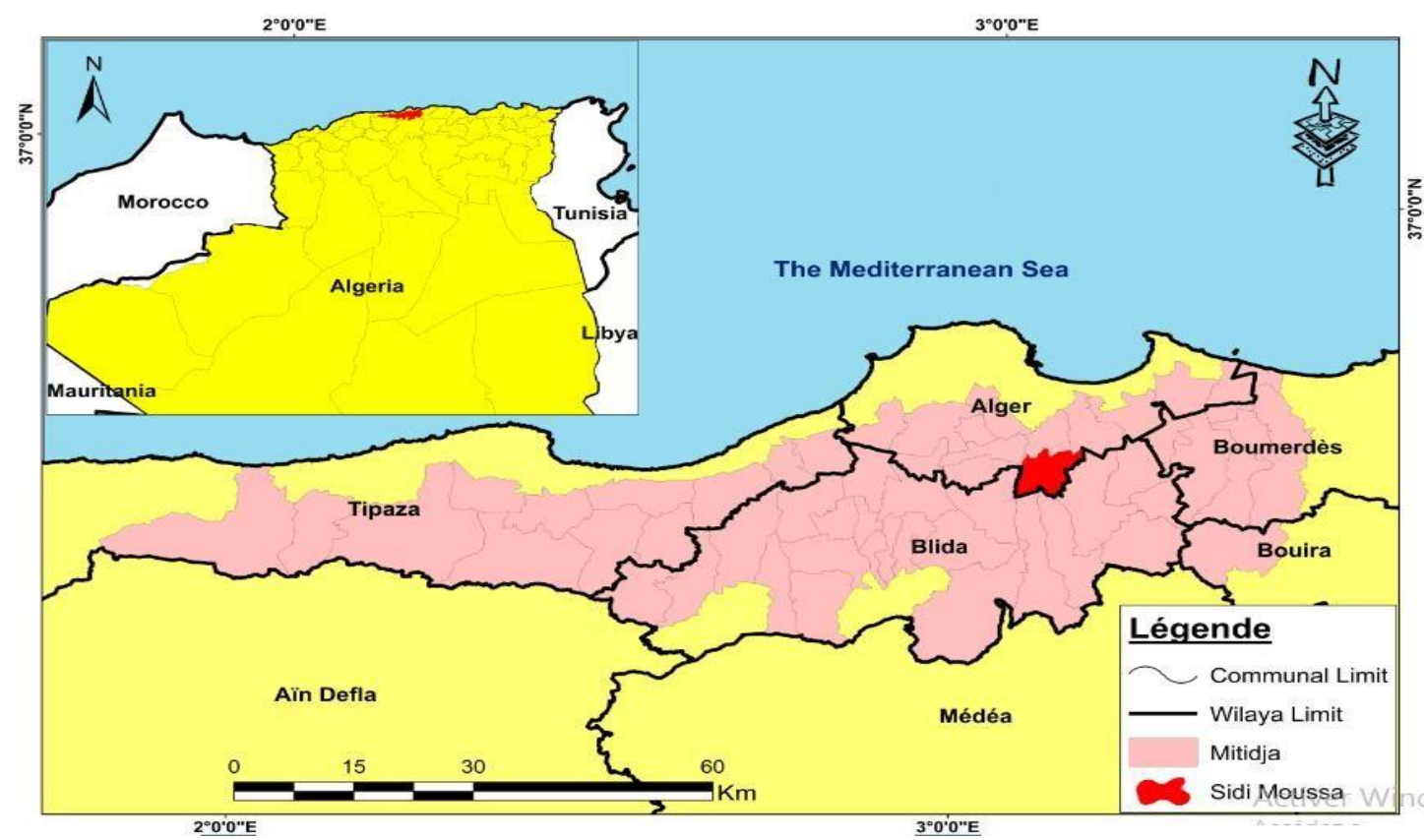

Figure 1. Location of the Sidi Moussa region, Algeria.

To explain the climatic conditions of Sidi Moussa, we have borrowed climatic data for 2017 and 2019 from the INRA (National Institute of Agricultural Research) Baraki weather station, which is located $3 \mathrm{~km}$ away from the study station. This data is presented in the following table:

Table 1. Monthly climate data records for the Mitidja Occidentale (Sidi Moussa) during the years 2017-2018 (INRA,2019)

\begin{tabular}{|c|c|c|c|c|c|c|c|c|c|c|c|c|c|}
\hline & & January & February & March & April & May & June & July & August & Sept. & Oct. & Nov. & Dec. \\
\hline \multirow{5}{*}{$\widehat{\bar{D}}$} & $\mathrm{~T}^{\circ} \mathrm{min}$ & 5.74 & 5.6 & 8.29 & 9.74 & 13.61 & 18.68 & 20.82 & 20.99 & 17.08 & 12.71 & 8.12 & 6.62 \\
\hline & $\mathrm{T}^{\circ} \max$ & 15.56 & 13.56 & 21.97 & 23.04 & 25.68 & 30.81 & 34.39 & 32.42 & 30.32 & 27.28 & 21.02 & 16.8 \\
\hline & $\mathrm{T}^{\circ} \mathrm{moy}$ & 10.14 & 9.68 & 14.56 & 16.27 & 19.44 & 24.57 & 26.85 & 26.27 & 23.46 & 19.71 & 13.63 & 11.36 \\
\hline & $\begin{array}{c}\mathrm{PP} \\
(\mathrm{mm})\end{array}$ & 195 & 27 & 41 & 7 & 2 & 11 & 0 & 0 & 29 & 16 & 103 & 148 \\
\hline & HR \% & 80.93 & 63.2 & 76.38 & 74.19 & 70.02 & 69.9 & 68.24 & 68.52 & 70.59 & 74.13 & 81.65 & 81.68 \\
\hline \multirow{5}{*}{$\stackrel{\infty}{\underset{N}{ٍ}}$} & $\mathrm{~T}^{\circ} \mathrm{min}$ & 6.24 & 5.46 & 9.15 & 10.51 & 12.35 & 15.7 & 19.92 & 20.03 & 19.34 & 14.31 & 10.66 & 7.11 \\
\hline & $\mathrm{T}^{\circ} \max$ & 18.7 & 16.05 & 19.54 & 22.19 & 23.26 & 28.32 & 32.42 & 32.18 & 30.62 & 25.65 & 21.91 & 21 \\
\hline & $\mathrm{T}^{\circ} \mathrm{moy}$ & 11.9 & 10.43 & 14.04 & 16.09 & 17.61 & 22.12 & 26.15 & 26.26 & 24.49 & 19.61 & 15.74 & 13.04 \\
\hline & $\begin{array}{c}\text { PP } \\
(\mathrm{mm})\end{array}$ & 49 & 135 & 132 & 105 & 33 & 40 & 0 & 0 & 24 & 66 & 110 & 35 \\
\hline & HR \% & 81.42 & 80.08 & 75.56 & 78.04 & 82.22 & 73.63 & 69.18 & 73.23 & 77.33 & 77.07 & 85.62 & 89.27 \\
\hline
\end{tabular}

Temperature analysis shows that low temperatures are recorded during the month of January and February. High temperatures are noted during the months of July and August during both years of the study. The annual rainfall for the year 2018 was high $(729 \mathrm{~mm})$ compared to the year $2017(579 \mathrm{~mm})$. The highest rainfall was recorded during the months of January and December in 2017, unlike the previous year when the highest cumulative rainfall was recorded during the months of February, March and November. On the other hand, the months of July and August remained the driest during both years. Relative humidity generally exceeded 60\% RH but remained higher in 2018 than in 2017. This uneven distribution of precipitation over the annual cycle and the alternation of wet and dry seasons plays a regulatory role in the biological activities of pests.

\section{Experimental design}

The study was carried out during two successive years, 2017 and 2018. Sampling was carried out every 10 days, three outing per month, with 72 outings in total. The study plot was divided into 9 blocks of 25 trees each numbered from 1 to 25 . The method used was inspired by that of Vasseur and Schvester (1957). We randomly selected two trees from each block from which we collected two leaves and a twig at random at $1.50 \mathrm{~m}$ from soil. For these samples, we did not take into account the age of the leaves or the diameter of the twigs from the four cardinal orientations plus the centre of the tree. Before being analysed in the laboratory, samples were placed in paper bags, which we immediately put in a cooler. The counting method consisted of identifying and counting - under a binocular magnifying glass - the different stages of the scale on the leaves and twigs. The number of living, dead and predated individuals were counted for each stage.

\section{Statistical analysis}

The variance analyses were performed on homogeneous averages in relation to a variance coefficient (C.V. - 20\%). The linear general model (GLM) was applied to the abundance of $I$. purchasi larvae and adults in order to study the spatial and temporal fluctuation of the population. Multiple comparisons were applied by using the Tukey Post Hoc test. The differences are considered significant at $\mathrm{p}<0.05$. The analysis was performed using Past software version 3.2. The availability barycentres were calculated according to Djazouli et al. (2009). The temporal barycentre was deduced from the following formula: $B=\Sigma(R G i \times A B i) / \Sigma A b i$, with $\mathrm{RGi}=$ rank from January to December) and $\mathrm{ABi}=$ abundance in month $\mathrm{i}$. 


\section{Results}

\section{Larval and adult population abundance}

Larvae stages were the most abundant during the two years of study with 13323 individuals (62.79\%) and 13968 individuals (54.39\%) in 2017 and 2018 respectively compared to 7896 individuals (37.21\%) in 2017 and 11715 individuals (33.50\%) in 2018 of adults (Figure 1).

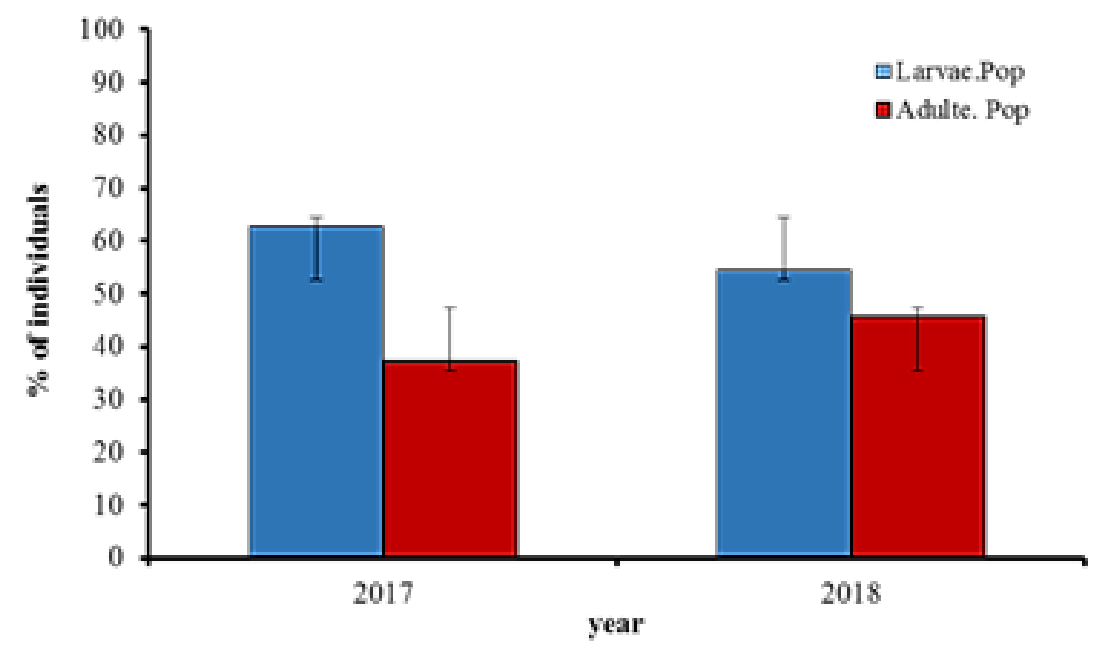

Figure 1. Global abundance of $I$. purchasion the clementine tree in the region of Sidi Moussa in 2017 and 2018.

\section{Evolution of the scale}

The level of $I$. purchasi infestation was very high over the studied period, with the minimum threshold exceeding 400 individuals during the two years. The scale population showed three infestation peaks: spring, summer and autumn. In 2017, the first peak was recorded in the first decade of April, with 700 individuals while in 2018 it was recorded in the third decade of March, with 1070 individuals, a 20-day lag. The second peak was observed towards the last decade of June in 2017 (850 individuals) and 2018 (920 individuals). Finally, the 3rd peak was observed on September, 19 (820 individuals) for 2017 and September, 5 (985 individuals) for 2018, a delay of about 15 days (Figure 2).

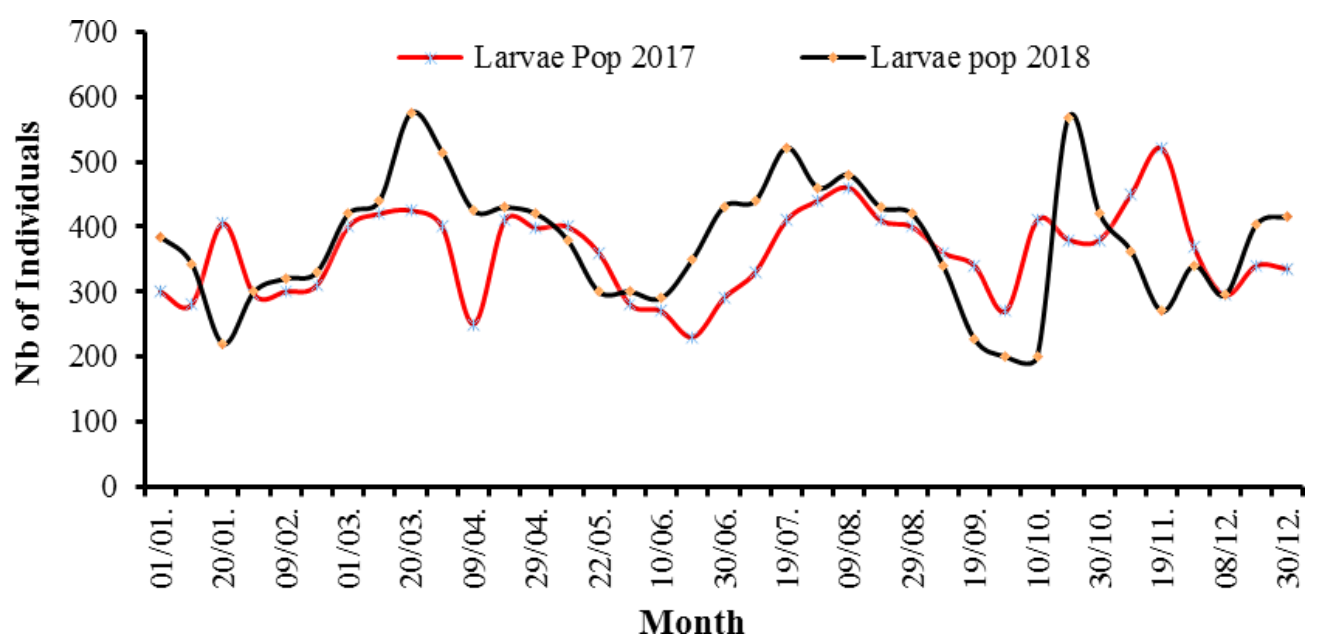

Figure 2. Change in the global population of $I$. purchasi on the clementine trees in Sidi Moussa in 2017 and 2018.

The overall annual abundance did not show a significant difference $(p=0.98)$ among months. The temporal profile showed a stable abundance even though some months showed significant numerical peaks (statistically there is no difference). The 2018 campaign was the most important in terms of overall effectiveness (GLM, $p<0.01$, Tukey test $p<1 \%$ ). The shape of the curves relating to fluctuations in adult populations and larvae shows an alternation of fluctuations where we can observe three periods of intense development: spring, summer and autumn (Figs. 3 and 4). Analysis of the results reported in Fig. 3 shows that variations in the numbers of larvae and adults are significant during the study period. For larvae, a first peak of 398 individuals was recorded on May, 15, a second peak of 460 individuals on August 9 and 520 individuals was recorded on November, 11 in 2017. In 2018, a first peak of 420 individuals was recorded on April, 29, delayed about 15 days compared to 2017. The second peak was noted on July, 19, with 522 individuals, delayed about three weeks compared to 2017. Finally, the third peak was noted on October 20 (568 individuals), delayed about four weeks compared to 2017. 


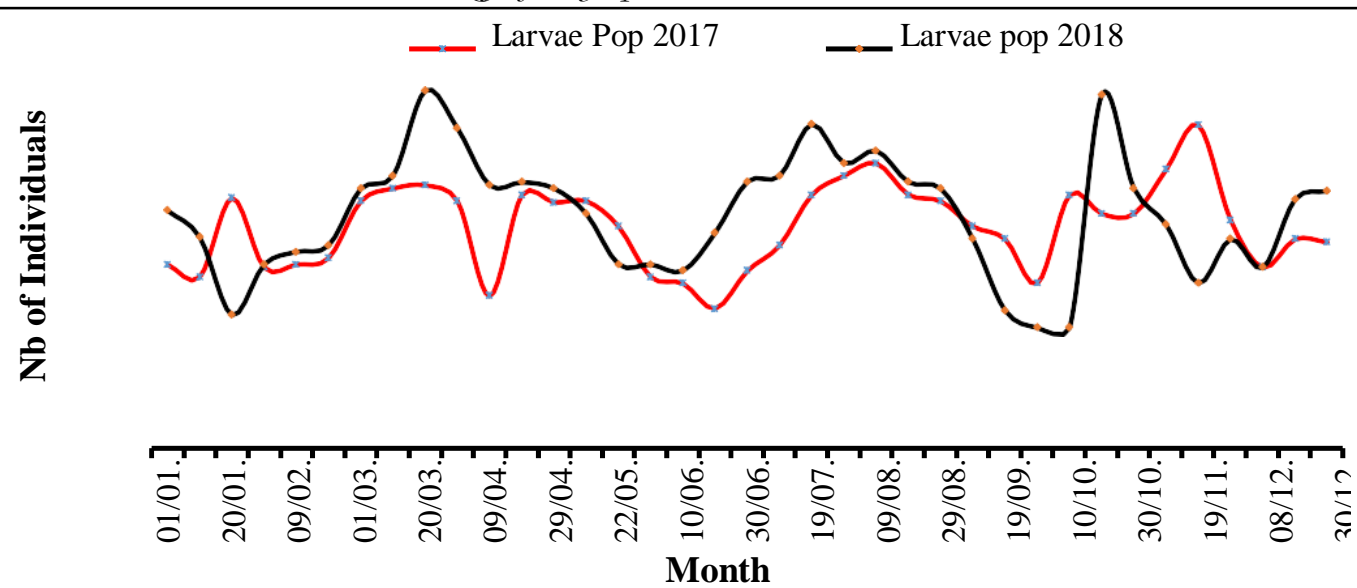

Figure 3. Spatial and temporal variation of larval stages of $I$. purchasi on clementine trees in Sidi Moussa

The temporal variation of the adult stage (adult females and laying females) is shown in Figure 4. Adult females followed the same pattern of larvae (Figure 4). Nevertheless, the population level of adults in 2018 (11,715 individuals) was significantly higher than in 2017 (7,896 individuals). However, in 2017 three maximum values were recorded: 450 females on 9 of April, 620 individuals on 20 of June and 480 individuals on 19 of September. In 2018, three population peaks were also recorded: on 10 of March, with 595 individuals, on 20 of June, with 570 individuals, and on 5 of September, with 645 individuals.

A comparison by level (month/month) was carried out using the Wilcoxon test and confirmed by the Monte Carlo test. With reference to the associated probabilities, larval abundance did not show a significant difference between the two surveys.

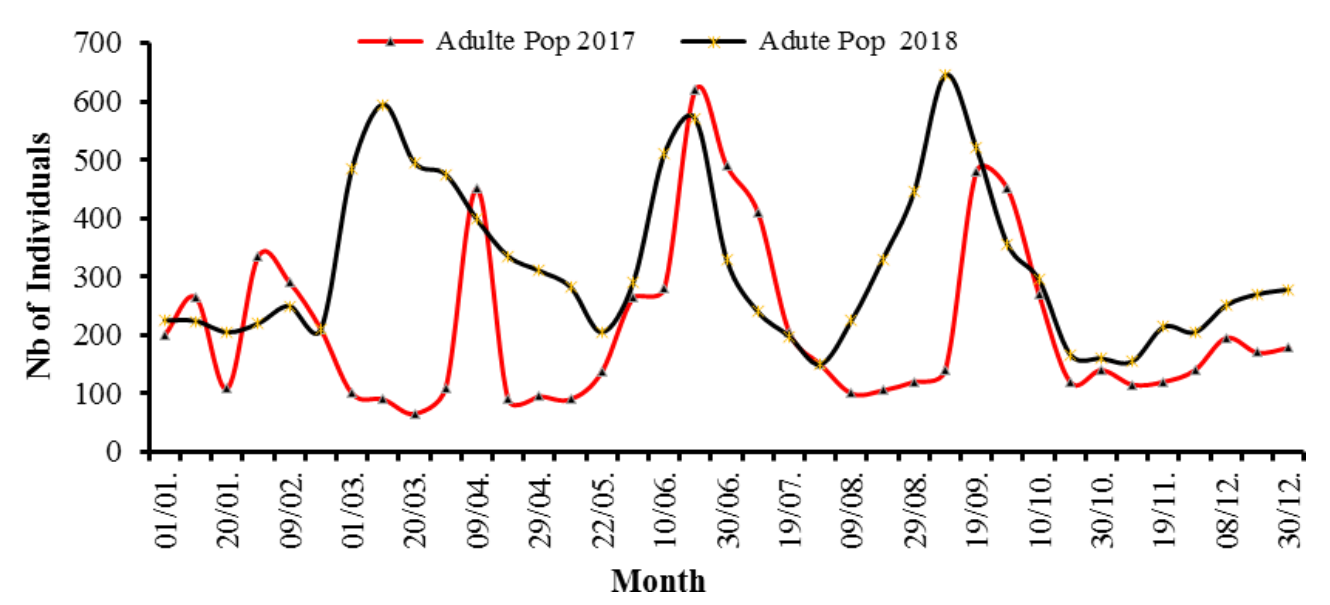

Figure 4. Spatial and temporal variation in the adult stages of $I$. purchasi on the clementine tree in Sidi Moussa in 2017 and 2018.

The same tests, was repeated for adult and laying females. The results showed that the populations in the 2018 season were significantly large in terms of abundance compared to the 2017 season $(p<0.03)$

We calculated the barycentre of the global abundance in order to estimate the time lag between the two years. The values were 6.44 and 6.25 respectively for 2017 and 2018. Thus, the maximum global abundance was reported around mid-July for both surveys. The Cross-correlation Test showed the presence of a time lag $(p=0.0371)$.

Table 2. Temporal shift of the different generations of $I$. purchasi on the clementine tree in Sidi Moussa.

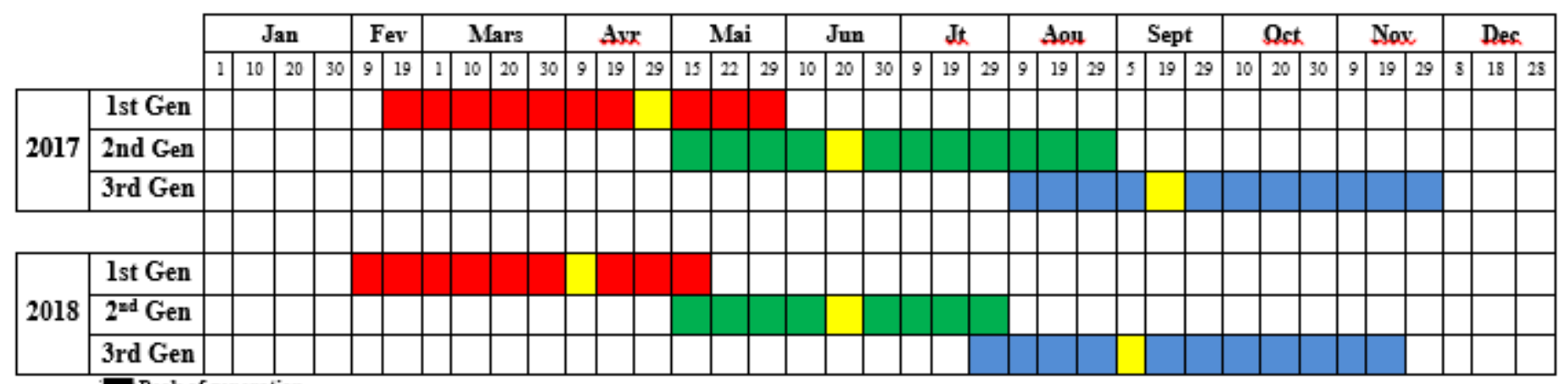




\section{Fertility study}

The overall average fertility of scale insects was 612.97 eggs/female in 2017 and 616.49 eggs/female in 2018. As before, the average fecundity during the two years also passes through three egg-laying peaks. In 2017, there were 1425.72 eggs/female in April, 647.58 eggs/female in June and 624.82 eggs/female in September. In 2018, the same periods of high average fertility will continue: April (1007.83 eggs/female), June (811.30 eggs/female) and September ( 971.45 eggs/female).

Females had the same fertility during both years $(p>0.05)$. We calculated the fertility barycentre to estimate the time lag between the two years. The values were 5.56 and 6.56 for 2017 and 2018, respectively. Thus, maximum fertility in 2017 was reported in mid-June, while maximum fertility was reported in mid-July for 2018. The Cross-correlation Test showed a very significant time lag from one month to another $(p=0.0064)$.

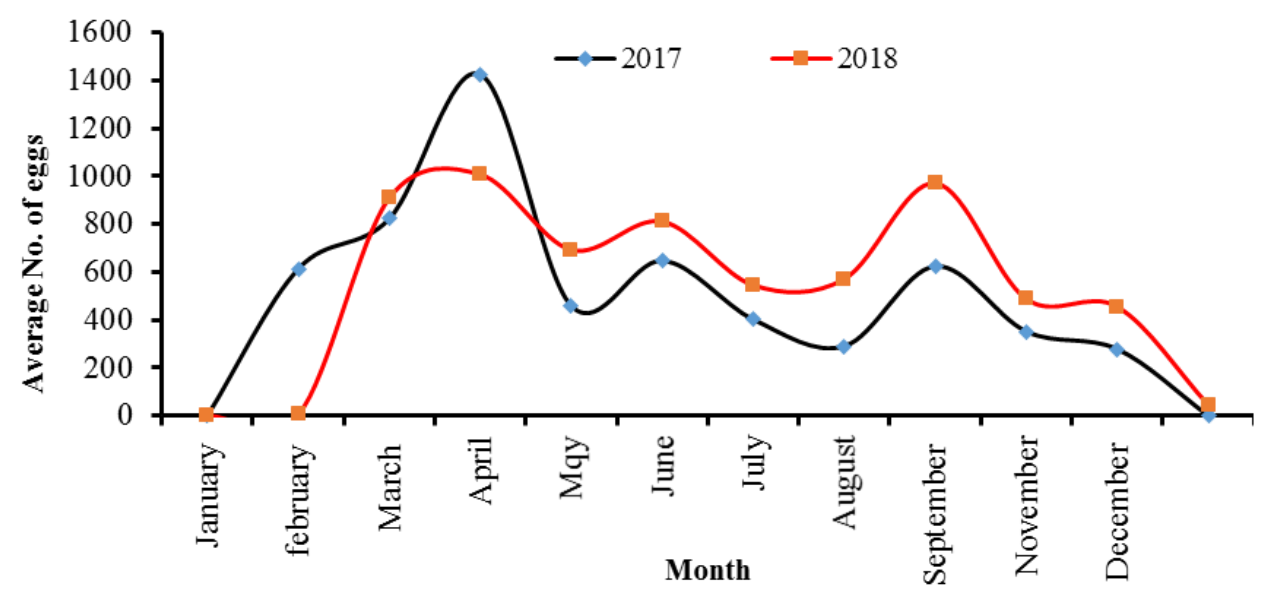

Figure 5. Fluctuation in average fertility in I. purchasion the clementine tree in Sidi Moussa in 2017 and 2018.

\section{Discussion}

Observations on the population dynamics of $I$. purchasi on clementine orchards were obtained during two years. Larval populations were higher than adult in both years. The monitoring of the fluctuations of the scale insect populations revealed the presence of three periods of higher abundance of scale on the clementine trees in Sidi Moussa during the two years of study in spring, summer and autumn. This is in close correlation to the host plant and can be explained by the abundance of nutrients from the spring $\left(\mathrm{PS}_{1}\right)$, summer $\left(\mathrm{PS}_{2}\right)$ and fall $\left(\mathrm{PS}_{3}\right)$ sap flushes. This biological aspect of I.purchasi shows the important role played by the host plant on the scale insect population density. Indeed, Biche and Sellami (1999) noted that the influence of the host factor on the mealy bug is revealed on cycle length, size, fecundity and sex ratio. Similarly, Begon et al. (1996) mentioned that the evolution of scale insects is closely related to that of the host plant and that the evolution of the host plant results in the appearance of new sap flushes. In this sense, Takarli et al. (2015) points out that the spring period is the most favourable season for this scale insect. It should be noted that the mealy bug behaves differently depending on the year. Indeed, we found a clear lag in days in the development of the populations of $I$. purchasi. The three periods of activity of $I$. purchasi in 2018 started early compared to those of 2017.

Studies conducted on this species showed that the scale develops between 2 to 5 annual generations. In Palestine, I. purchasi can develop 3 to 5 generations per year (Bodenheimer, 1951; Avidov and Harpaz, 1969). On the other hand, in northwestern Argentina, the species develops in 3 generations (Nasça et al., 1981) and only in Valdivia in Chile (Reboledo and Carrillo, 1988). In mainland Europe, particularly in Portugal, it is possible to have four annual generations, but the general rule is three, with breeding activity in

February, July and September (Amaral, 1982; Soares, 1980). The same results were reported by Garrido and Busto (1987) and Climent (1990), who point out that in Italy the scale can develop three generations with larval hatching in February, June and September but only two generations in Antibes (southern France), as in Spain, where three generations were reported. Further south, in Morocco, I. purchasi evolves in four annual generations where the first one between February and June, the second one between June and August and the third one from August to October and the last one in winter. These numbers of generations are probably due to the effects of temperature. Studies conducted by Ghanim et al. (2013) in Egypt show that $I$. purchasi also develops three generations. On the other hand, Awadalla (2017) reports that $I$. purchasi recorded only one peak in abundance on Grenadier in early September. Overwintering mainly affects the young female and adult female stage associated with second and third instar larvae. These results reinforce the evolution of the average fertility of the scale, which also goes through three periods of egglaying.

There is a close relationship between scales and their host plants. These come as a real ecological factor, the action of which is superimposed on that of climatic factors (Biche, 1987). Several authors classified the host plants of the species as "normal"hosts (primary or main), which allow the insect to develop and multiply fairly regularly. As "secondary" hosts, which allow the development with little or no multiplication was observed and on which the infestation may decrease slowly; and as "exceptional" (or occasional) hosts, which just allow the insect to develop, but on which the infestation declines rapidly. The host plant affects the development time, the individual size, the fecundity and the sex ratio.

\section{Conclusion}

We concluded that the Australian scale presents three periods of activity on the clementine tree in Sidi Moussa: during autumn and spring. They coincide perfectly with the three shoots of sap of the clementine or orange tree. These periods probably offer the cochineal favourable conditions for its development. Spring seems to be the most favourable season scale insect populations. The rate of development during this season is the highest compared to other seasons. Scale insect fecundity is influenced by ecological factors. Egg-laying occurs throughout the year, resulting in generational overlap, which, in relation to other seasons, remains higher in spring and fall. 


\section{References}

Abd-Allah, L. A. (1988). Studies on predator and parasite insects attacking scale insects and mealybugs in Dakahlia Governorate. Ph.D. Thesis. Mansoura Univ.

Alvis, L., Raimundo, A., Villaba, M., Grcia, M.F. (2002). Identification and abundance of Coccinellidae (Coleoptera) in citrus orchards in Valencia (Spain). Boletin-de-Sanidad-Vegtal-Plagas, 28(4), 479-491.

Amaral J.D. (1982). Os Citrinos. Colecçào Técnica Agrària. Clàssica Editora.

Aroua, Kh., Belguendouz, R., Kaidan, M.B., Achiri, T.D., Biche, M. (2019). Les cochenilles des agrumes (clémentinier et oranger) dans deux regions de la Mitidja (Rouiba et Oued El Alleug) (Algérie). Revue Agrobiologia, 9 (2), 1707-1714.

Aroua, Kh., Kaydan, M.B., Achiri, T.A., Biche, A. (2020). The influence of the region and the host plant on population dynamics of Parlatoria ziziphi (Lucas) (Hemiptera: Diaspididae) in Mitidja (Algeria). Eco. Env. and Conserv, 26(1), 333-340

Avidov, Z., Harpaz, I. (1969). Plant pests of Israel. Israel Universities Press.

Awadalla Hagar, S.S. (2017). The Population Abundance of the Mealybug Species Infesting Pomegranate Trees and their Associated Insect Predators in Mansoura Region, Egypt. J. Plant Prot. and Path., Mansoura Univ., 8(1), 15- 19, 2017.

Bailet, J-M. (2011). Les ravageurs des Agrumes. Journée Biologique du Phoenix, 405, Promenade des Anglais, 06200 Nice, 9-13.

Begon M., Harper J.L., Townsend, C.R. (1996). Ecology, Individuals, Ecology, Individuals, Populations and Communities Populations and Communities, Blackwell Science Ltd., Australia.

Belguendouz, R. (2014). Relations plantes hôtes cochenilles diaspines sur les agrumes (Citrus ssp) en Algérie: cas de Parlatoria ziziphi (Lucas, 1853) (Homoptera : Diaspididae). Thèse. Doct., Ecol. Nat. Sup. Agro, El Harrach (Alger).

Biche M. (1987). Etude biologique d'Aphytis maculicornis M. (Hym. Aphelinidae) parasite externe de Parlatoria oleae C. (Hom. Diaspididae) ravageur de l'olivier dans la région du Cap Djinet pour une éventuelle lutte biologique, 119-145

Biche, M. (2012). Les principaux insectes ravageurs des agrumes en Algérie et leurs ennemis naturels. Ed. FAO., Regional Integrated Pest Management Programme in the Near East / GTFS/REM/070/ITA.

Biche, M., Sellami, M. (1999). Etude de quelques variations biologiques possibles chez Parlatoria olea (Colvée) (Homoptera: Diaspididae). Bull. Soc. Ent. Fr., 287-292.

Bodenheimer, F. S. (1951). Citrus entomology in Middle East. Uitgeverij Dr W. Junk, S. Gravenhage.

Boudi, M. (2005). Vulgarisation agricole et pratiques des agrumiculteurs de la Mitidja. Institut national agronomique, El Harrach, Alger.

Carvalho, J. P., Franco, J.C., Aguiar, M. R, Soares, A. O. (1996). Insect pests of citrus in Portugal. VIll Congress of the International Society of Citriculture. 12-17.05.1996. Sun City, South Africa.Proc. Int. Soc. Citriculture, I, 613-618.

Causton, C.E., Lincango, M.P. and Poulsom, T.G. (2004). Feeding range studies of Rodolia cardinalis (Mulsant), a candidate biological control agent of Icerya purchasi Maskell in the Galapagos Islands. Biol. Control, 29, 315-325.

Chafaa S., Biche M., Chenchouni H. Sellami M. et Sibachir A. (2013a). Effet de la dynamique de l'exposition sur la dynamique des populations de la cochenille violette, Parlatoria oleae Colvée (Hemiptera: Diaspididae) en conditions arides. Ann. Soc. Entomol. Fr., 49(3), 291-297

Chafaa, S., Biche, M., Chenchouni, H. Sellami, M., Sibachir, A. (2013b). Cycle biologique de Parlatoria oleae (Hemiptera: Diaspididae) inféodée aux oliveraies dans une région aride. Can. Entomol., 145, 1-8.

Climent, J. M. L. (1990). Homópteral Cochinillas de los cítricos y su control Biológico. Pisa Ediciones.

DeBach, P. (1964). Biological control of insect pests and weeds. Reinhold, New York.

Garrido, A., Busto, T. Del. (1987). Algunas cochinillas no protegidas que pueden originar daños en los cítricos españoles, I: Icerya purchasi Mask (subfamilia: Margarodinae). Levante Agrícola, 267-268, 63-71.

Ghanim, A.A., Abdel-Salam, A.H., Elkady, H.A., El-Nagar, M.E., Awadalla Hagar, S.S. (2013). Ecological studies on some mealybug species attacking mandarin trees and their predatory insects at Mansoura district. J. Plant Prot. and Path., Mansoura Univ, 4(3), 303-315.

Hoddle, M. S. (2004). Restoring balance: Using exotic species to control invasive exotic species. Conservation Biology, 18, 38-49.

Hughes, S.S. (1930). Contributions to the Life History of the Iceryine Coccids, with special reference to parthenogenesis and hermaphroditism. Ann. Entomol. Soc. Am, 23, 359-380.

Kiyindou, A. (2008). Contribution à l'étude de l'écologie et de la biologie des homoptères ravageurs des arbres fruitiers et autres plantes: Il: influence de la plante-hôte et de sa phénologie sur l'évolution des infestations d'Aleurodicus dispersus RUSSELL (Hom.: Aleyrodidae) en république du Congo. Tropicultura, 1, 10-15 (in French).

Mbete P., Itoua A.Ch.M., Kiyindou A., Ngokaka Ch., N'doungou, J-P. (2011). Evaluation des dégâts causés aux Agrumes par la Cochenille (Praelongorthezia proelonga) dans les quartiers Sud de la ville de Brazzaville. J. Appl.Biosci 39, 2619-2625 (in French).

Noureddine, M., Khaoula, A., Aissa, M., Abdelmadjid, B., Biche, M. (2016). Biological data on Pollinia pollini (Coccoidea: Asterolecaniidae) on Olive tree in Mitidja (Algeria). Wulfenia Journal, 23(3), 162-169

Mutin G. (1977). La Mitidja: décolonisation et espace géographique. Ed. Office Publ. Univ. Alger. Cent. Nat. Rech. Sci., Paris (in French).

Nasca, A. J., Terán, A.L., Fernández, R. V, Pasqualini, A. J. (1981). Animales prejudiciales y benéficos a los cítricos en el noroeste Argentino. CIRPON (in French).

Nowrin, S., Begum, M., Khatun, M., Howlader, M.A. (2019). The abundance and mechanical control of Icerya purchasi (Maskell) (Hemiptera: Monophlebidae) on mangifera indica in Dhaka, Bangladesh. Bangladesh J. Zool, 47(1), 89-96.

Robolledo. R., Carrillo. R. (1988). Ciclo estacional, fenología y plantas hospederas de Icerya purchase Maskell en Valdivia, Chile. Rev. Chilena Ent., 16, 25-32.

Soares, J.A.C. (1980). A protecção dos citrinos. Ministério da Agricultura e Pescas. Direcção Regional de Agricultura do Algarve.

Takarli, F., Belguendouz, R., Benrima, A. (2015). Etude de la dynamique des populations de Parlatoria ziziphi Lucas sur clémentinier dans la région de Mitidja. Rev. Agrobiologia, 7, 21-26

\section{Citation:}

Boukhobza, L., Belguendouz, R., Biche, M. (2020). Ecology of Icerya purchasi Maskell, 1879 (Homoptera: Margarodidae) on clementine trees at Sidi Moussa (Central Mitidja, Algeria). Ukrainian Journal of Ecology, 10(5), 296-301.

This work is licensed under a Creative Commons Attribution 4.0. License 